\title{
KONTESTASI PARA WARIA DALAM PERTUNJUKAN \\ KETOPRAK LAKON ANDE ANDE LUMUT OLEH PAGUYUBAN SENI SEDAP MALAM SRAGEN: SEBUAH KAJIAN PERFORMATIVITAS GENDER
}

\author{
Wahyudi \\ Institut Seni Indonesia Surakarta \\ dodokyudi@gmail.com
}

\begin{abstract}
Abstrak: Penelitian ini menganalisis performativitas para waria dalam menunjukkan identitas dan pilihan gender mereka. Kajian ini menggunakan teori performativitas gender Judith Butler, di mana identitas dianggap sebagai sebuah performansi. Hasil penelitian menunjukkan bahwa pertunjukan ketoprak Sedap Malam merupakan kontestasi para waria. Para waria berlomba-lomba untuk menunjukkan kualitas kefeminitasannya. Kontestasi itu dilakukan dengan aksi, ekspresi, gestur, dandanan, pakaian, dan semua tindakan para waria yang dilakukan secara heboh dan berlebihan. Kehebohan itu dilakukan untuk meneguhkan keperempuanannya, karena selamanya mereka dihantui bahwa meskipun gendernya adalah feminin, tetapi masyarakat tetap melihat berdasarkan sex. Oleh karena itu mereka akan terus meyakinkan masyarakat bahwa dirinya adalah perempuan. Peneguhan yang menggebu-gebu atas kefeminitasannya itu dilakukan secara hiperbolis bahkan terkadang menjadi sangat ekstrim.
\end{abstract}

Kata kunci: Sedap Malam, waria, ketoprak, dan performativitas gender

\begin{abstract}
This study analyzed the performance of transvestites in showing their gender identity and choices. This study used Judith Butler's (1993) gender performance theory, where identity is considered as a performance. The results showed that the Sedap Malam ketoprak performance was a contestation for transvestites. The transvestites are competing to show the quality of their femininity. The contestation was carried out with splashy actions, expressions, gestures, make-up, clothes, and all the transvestites behavior were carried out exaggerate. The excitement was carried out to strengthen their womanhood because they were always haunted that even though their gender was feminine, people continued to look them based on their born-sex. Therefore they will continue to convince the public that they are women. Enthusiastic affirmation of their enthusiasm was done hyperbolically and sometimes even very extreme.
\end{abstract}

Key words: Sedap Malam, transvestites, ketoprak, gender performativity

\section{Pendahuluan}

Tiga orang dengan memakai busana kebaya warna merah, biru, dan hijau memasuki panggung. Mereka bertiga menari dengan begitu luwesnya. "Mereka laki-laki atau perempuan?" tanya salah satu penonton. "Yang memakai kebaya biru dan hijau itu waria, tapi kalau yang memakai kebaya warna merah sepertinya perempuan" jawab penonton yang lain. "Ngawur! Mereka bertiga semuanya waria", jawab penonton yang lain lagi agak berteriak. "Yang memakai kebaya warna merah cantik dan luwes ya", penonton lainnya lagi 
berkata dengan ekspresi takjub. Itulah reaksi para penonton ketika menonton pementasan Ketoprak Sedap Malam dengan lakon Ande Ande Lumut oleh Paguyuban Seni Sedap Malam Sragen.

Paguyuban Seni Sedap Malam Sragen dipimpin oleh Sri Riyanto, ia satu-satunya lelaki tulen di grup itu. Sebagaimana seniman seni tradisi lainnya ia juga piawai dalam bidang seni tari, karawitan, dan ketoprak. Dalam setiap pementasannya Sri Riyanto memberikan ruang bagi para waria untuk menentukan kebebasan dirinya di atas panggung. Pola akting pelaku atau aktor dalam pementasan ketoprak Sedap Malam tidak jauh berbeda dengan ketoprak atau seni pertunjukan tradisi lainnya. Para pelaku atau aktor menggunakan pendekatan atau pola akting yang natural dan spontan.

Selama ini kelompok termajinalkan termasuk waria belum mendapat tempat sebagaimana kelompok heteronormativitas. Di Indonesia, heteronormativitas menjadi ideologi dominan yang dilanggengkan penguasa. Waria menjadi salah satu yang dianggap kebanyakan orang sebagai sesuatu yang negatif . Mohamad Yasir Alimi (2004) dalam bukunya, Dekonstruksi Seksualitas Postkolonial: dari Wacana Bahasa hingga Wacana Agama, menyimpulkan bahwa heteronormativitas masih menjadi wacana dominan yang dikonstruksi oleh media mainstream. Kehidupan para waria Sedap Malam Sragen oleh sebagian masyarakat Sragen dianggap menyimpang. Sebagian masyarakat Sragen belum mampu menerima waria karena menganggap para waria melanggar norma dan nilai yang dianut masyarakat.

Para waria Sedap Malam masih mengalami ketidakadilan dalam kehidupannya. Para waria Sedap Malam sebagai warga Negara susah mencari kerja karena identitas. Para waria Sedap Malam sebagai angota masyarakat mengalami pelecehan verbal dan fisik karena nilai dan norma masyarakat. Para waria Sedap Malam sebagai angkatan kerja mendapat diskriminasi pekerjaan karena konstruksi gender. Oleh karena itu pementasan ketoprak Sedap Malam dengan kecairan sifatnya dianggap mampu menjadi media alternatif untuk menyuarakan 'ketertindasan' para waria, khususnya dalam menunjukkan identitas mereka. Selain itu pergeseran posisi subjek dalam kacamata posmodernitas, dimana subjek-subjek kecil mulai memiliki suara untuk menentang struktur kuasa, memungkinkan para waria sebagai subjek kecil untuk dapat berbicara, mengungkap identitas gender mereka.

Berangkat dari masih sedikitnya penelitian yang mengkaji tentang komunitas marjinal, utamanya waria dalam kaitannya dengan sebuah pertunjukan seni, maka penelitian ini fokus mengkaji mengenai hal tersebut. Kajian ini mengupas mengenai performativitas identitas yang tampak pada pementasan ketoprak Sedap Malam Sragen. Kajian ini menggunakan teori performativitas gender Judith Butler, di mana identitas dianggap sebagai sebuah performansi. Mengingat bahwa permasalahan performativitas bukan hanya mengenai bagaimana seseorang atau sesuatu ditampilkan, namun juga mengenai apa maksud yang melatar-belakangi penampilan tersebut, maka penelitian ini lebih fokus pada kontestasi para waria dalam pementasan ketoprak lakon Ande Ande Lumut oleh Paguyuban Seni Sedap Malam Sragen. Fokus tersebut dilihat dari bagaimana para waria tersebut mengimpersonasi tokoh dalam lakon namun tetap menjadi dirinya sendiri dan saling bergantian memunculkan ekspresi dan gestur yang dilebih-lebihkan, bagaimana para waria mengungkapkan ekspresinya, dan bagaimana sikap para waria memenuhi hasrat ingin diakui sebagai perempuan.

Teori yang digunakan untuk membedah kontestasi para waria yaitu teori 
performativitas gender Judith Butler. Performativitas Gender sebagai teori digunakan sebagai cara untuk melihat kontestasi para waria, yaitu mengenai bagaimana para waria menunjukkan dan membuktikan kualitas feminitasnya, keluwesan gerak, kelembutan, dan kecantikan. Kontestasi terjadi karena subjek tidak akan pernah bisa untuk memenuhi hasratnya, maka sikap subjek akan terus berproses untuk menjadi subjek yang utuh.

Butler menggambarkan bagaimana kebenaran tentang gender dan seksualitas diproduksi dan direproduksi melalui serangkaian tindakan, gestur, dan hasrat yang mengimplikasikan identitas gender paling esensial. Waria, objek yang dikaji Butler, harus melakukan serangkaian praktik dan prosedural tertentu untuk memperoleh bentuk yang diidealkan di mana gestur dan penampilan mereka dianggap feminin. Praktik ini bagi mereka, menurut Butler, tidak sekedar menirukan femininitas perempuan. Lebih jauh, mereka juga menunjukkan bahwa femininitas adalah sebuah praktik peniruan, baik itu ketika dilakukan waria maupun perempuan. Singkatnya, penentu the effect of realness adalah kemampuan untuk menghasilkan naturalised efeect (Butler, 1993).

Dengan demikian, bahwa waria bukan sedang meniru yang asli, melainkan menginspirasikan bahwa yang asli itu tidak ada, yang ada hanyalah layers of performances hingga membentuk efek yang benar-benar dianggap alamiah. Tidak ada identitas gender di balik ekspresi gender, karena gender adalah sebuah proses imitasi, pengulangan dan performativitas yang tidak pernah berhenti. Artinya, identitas gender bukanlah sebuah hal yang tetap.

Lebih jauh dan mendalam Butler mengatakan bahwa jika gender dan seksualitas itu berbeda secara radikal, gender tidak perlu mengikuti seks yang terberi untuk menjadi sebuah gender yang terberi; dengan kata lain "perempuan" tidak harus konstruksi kultural atas tubuh perempuan, dan "laki-laki" tak perlu menafsirkan tubuh laki-laki. Formulasi radikal perbedaan seks/gender ini mengisyaratkan sexed bodies memiliki kesempatan menjadi bermacam-macam gender, dan lebih jauh, gender itu sendiri tidak perlu dibatasi hanya dua. Jika seks tidak membatasi gender, tentu ada banyak gender, yaitu cara menafsirkan the sexed body, yang tidak dibatasi dualitas jenis kelamin. Coba pikirkan konsekuensi lebih jauh jika gender adalah sesuatu yang mana seseorang menjadi-tetapi tidak pernah bisa-maka gender itu sendiri adalah semacam proses menjadi atau aktivitas, tidak sepatutnya diperlakukan sebagai kata benda atau sesuatu yang substansial atau penanda budaya yang statis, tetapi sebagai tindakan yang terus-menerus dan tidak pernah berhenti (Butler, 1990).

Gagasan sentral pemikiran Judith Butler adalah performativitas gender dan seks. Gender, bahkan seks, bagi Butler adalah "pertunjukan", bukan esensi, atau ekspansi seks yang ada pada tubuh. Ide performativitas berasal dari ketidakpuasan penjelasan pascastrukturalisme bahwa tidak ada tubuh yang mendahului pemaknaan. Pertanyaan itu dijawab dengan performativitas. Kemudian yang tertinggal adalah bagaimana halnya dengan materialitas tubuh dan materialitas seks? Di sinilah kemudian Butler mengembangkan konsepnya lebih jauh mengenai "materialitas seks". Materialisasi merupakan proses pembentukan menjadi material, menjadi daging, menjadi darah, yang tidur, makan, dan istirahat. Bagi Butler tubuh-saraf, darah, kontur dan gerakannya termaterialkan oleh performativitas oleh pertunjukan.

\section{Tinjauan Pustaka}

Kajian ini menempatkan diri dalam perspektif posmodernis. Kontestasi dalam 
penelitian ini adalah perlombaan antar para waria Sedap Malam, mereka berkontestasi saling menunjukkan dan membuktikan kualitas femininitasnya: keluwesan gerak, kelembutan, keanggunan, dan kecantikan. Kontestasi terjadi karena subjek tidak akan pernah bisa untuk memenuhi hasratnya, maka sikap subjek akan terus berproses untuk menjadi subjek yang utuh dan sempurna, meskipun hal itu tidak akan pernah bisa.

\section{Antara Keperempuanan dan Kelelakian}

Pencirian keperempuanan dan kelelakian adalah kerja budayawi. Jenis kelamin secara alami tidak menentukan bagaimana gestur, vokal dan keadaan jiwa seseorang. Konversi dari betina-jantan (yang alami) menjadi perempuan-laki-laki (yang budayawi) berlangsung secara paksa. Manusia betina menjadi perempuan karena diperempuankan, manusia jantan menjadi laki-laki karena dilaki-lakikan secara paksa.

Collard dan Contrucci (1988) dalam buku ekofeminis berpendapat bahwa semua perempuan dihubungkan dengan tubuh yang melahirkan anak dan ikatan dalam diri yang terkait dengan bumi alamiah yang mendukung nilai-nilai egaliter dan berbasis pengasuhan. Gilligan juga berpendapat bahwa kalau laki-laki banyak memberikan perhatian kepada soal 'etika keadilan', perempuan lebih banyak berpusat pada 'etika kasih sayang' (Barker, 2008). Artinya keperempuanan adalah ideologi yang berciri kedamaian, keselamatan, kasih, keselamatan dan kebersamaan, sementara kelelakian memiliki karakter persaingan, dominasi, eksploitasi dan penindasan.

Seks dan gender adalah konstruksi sosial dan budayawi yang tidak dapat direduksi ke dalam disiplin biologi. Artinya, keperempuanan dan kelelakian bukan merupakan kategori esensial universal dan abadi melainkan sebuah konstruksi diskursif. Dengan demikian akan memunculkan kemungkinan pada berbagai bentuk keperempuanan dan kelelakian. Kesimpulannya, berbicara tentang keperempuanan dan kelelakian adalah tentang bagaimana laki-laki dan perempuan direpresentasikan, diyakini sebagai arena perjuangan politik berkelanjutan dalam menemukan makna.

Berbicara tentang keperempuanan dan kelelakian adalah berbicara tentang subjektivitas. Berbicara tentang subjektivitas adalah juga berbicara tentang identitas. Berbicara tentang identitas berarti bertanya soal bagaimana melihat diri dan bagaimana orang lain melihat. Subjektivitas dan identitas adalah produksi budaya yang tidak menentu.

Giddens (1991) mengatakan identitas diri bukanlah sifat distingtif atau bahkan kumpulan sifat-sifat yang dimiliki oleh individu. Identitas adalah diri sebagaimana yang dipahami secara refleksif oleh orang dalam konteks biografinya. Jadi, identitas diri adalah apa yang dipikir tentang diri sebagai pribadi, tetapi identitas bukanlah kumpulan sifat-sifat yang dimiliki, bukanlah entitas atau benda yang bisa ditunjuk. Identitas adalah cara berpikir tentang diri, yang berubah dari satu situasi ke situasi yang lain menurut ruang dan waktunya. Identitas merupakan sesuatu yang diciptakan, sesuatu yang selalu dalam proses, suatu gerak maju ketimbang sesuatu yang datang kemudian. Proyek identitas adalah proses mengenai apa yang dipikir tentang diri saat ini yang dilihat dari situasi masa lalu dan masa kini, lalu dimuarakan kepada apa yang dipikir dan diinginkan yaitu lintasan harapan ke depan.

Identitas diri terbangun oleh kemampuan untuk melanggengkan narasi tentang diri, sehingga membangun suatu perasaan terus-menerus tentang adanya kontinuitas biografisnya. Berbicara mengenai identitas para waria Sedap Malam adalah mencari jawaban atas sejumlah 
pertanyaan penting: Apa yang harus dilakukan para waria Sedap Malam? Bagaimana para waria Sedap Malam melakukan aksi, baik dalam keseharian maupun dalam pertunjukan mereka? Dan para waria Sedap Malam ingin jadi siapa atau ingin menjadi diri yang bagaimana? Singkatnya, bagaimana para waria Sedap Malam merepresentasikan diri mereka.

Pertunjukan Sedap Malam adalah dunia yang membutuhkan hadirnya tubuh. Artinya, tubuh secara artifisial harus dihadirkan untuk mewakili identifikasi identitas diri. Lakuan aksi para waria Sedap Malam baik secara alami maupun artifisial bertujuan untuk menunjukkan keperempuanan mereka. Lakuan aksi para waria baik dalam pertunjukan maupun keseharian memang tidak berubah namun dalam konteks penampilan fisik akan terlihat juga kelelakian mereka. Para waria Sedap Malam rata-rata cenderung mengkombinasikan penanda-penanda gender yang tampak melalui penampilan tubuh. Dwi Utami yang terlihat paling 'perempuan' ketika dalam pertunjukan justru berpenampilan 'laki-laki' ketika di rumah.

Nining Kusim, Ambar Handoko, dan Santi Marwan adalah tiga nama anggota waria Sedap Malam yang sangat perempuan dalam penampilan keseharian. Ketiganya selalu melakukan rias wajah dalam keseharian. Rias wajah menjadi penanda penting bagi perempuan. Dari ketiga nama tersebut Nining Kusim yang paling dominan. Ia memiliki kecenderungan berpenampilan 'keperempuanan', Nining juga lebih sering memakai rok, pakaian berbentuk rok, bagi masyarakat kita, adalah pakaian buat perempuan. Rok identik dengan simbol feminitas. Namun, Dwi Utami menampilkan bentuk lain dari pilihan penggunaan rok sebagai identifikasi gender dirinya.
Bagi Dwi Utami, Cindi Kartolo, Sofi Supar, Puri Purwanto, Nuri Corong, dan Arista Aris, rok bukanlah pakaian seharihari yang merepresentasikan diri mereka. Mereka hanya menggunakan rok jika menghadiri acara resmi, misalnya resepsi pernikahan. Bahkan Cindi Kartolo, Nuri Corong dan Sofi Supar lebih terlihat sisi kelelakian mereka dalam penampilan fisik keseharian. Sofi Supar sering terlihat mengenakan celana tentara dipadu dengan kaus kutang, sementara Cindi Kartolo dan Nuri Corong sering memakai celana jeans pendek pria dipadu kaos oblong.

Lebih lanjut Dwi Utami menceritakan bahwa Nining Kusim memiliki 'ritual' menyisir rambut, membersihkan wajah, memakai bedak, memakai gincu, mengenakan rok, memakai aksesoris perempuan, dan menyemprotkan minyak wangi. Nining Kusim selalu membawa tas wanita dan pasti selalu berisi perlengkapan Keperempuanan seperti; tisu, sisir, bedak, kaca cermin, gincu, minyak wangi, jepitan rambut dan lain-lain. Penyebutan 'perlengkapan keperempuanan' di sini menegaskan bahwa alat rias memang selalu menjadi penanda bagi gender perempuan.

Ambar Handoko dan Santi tertular oleh kebiasaan-kebiasaaan Nining Kusim untuk ikut-ikut menunjukkan keperempuanan. Bahkan mereka berdua selain memakai gelang, kalung, cincin, dan anting juga mengenakan BH. Bagi Nining Kusim, Ambar Handoko, dan Santi Marwan ketika berdandan dalam keseharian tak ubahnya seperti ketika mereka pentas tari atau ketoprak. Mereka melakukannya karena sebagai subjek mereka tidak pernah terpuaskan untuk menunjukkan keperempuanan mereka.

\section{Metode}

Metode dalam penelitian ini menggunakan pendekatan emik, yaitu pendekatan yang mendasarkan pada sudut 
pandang partisipan (informan). Dengan pendekatan emik pernyataan-pernyataan menjadi lebih akurat pada saat penulis mengungkap persamaan dan perbedaan pendapat di lapangan, selanjutnya dicari signifikansi dan makna secara penuh. Pendekatan emik lebih memandang makna budaya lebih aspiratif. Jenis penelitian yang digunakan dalam penelitian ini adalah penelitian deskriptif analitik. Penelitian deskriptif analitik dilakukan dengan cara mendeskripsikan fakta-fakta yang kemudian disusul dengan analisis (Ratna, 2004). Data berupa data-data kualitatif yang pengungkapannya bersifat deskriptif sehingga memberikan penjelasan yang cukup.

\section{Hasil dan Pembahasan}

Gender: Reproduksi Tanda

Gender adalah sesuatu yang mana seseorang menjadi (tetapi tidak pernah bisa) atau aktivitas, tidak sepatutnya diperlakukan sebagai kata benda atau sesuatu yang substansial atau penanda budaya statis, tetapi sebagai tindakan yang terus-menerus dan tidak pernah berhenti (Butler, 1990). Bagi Butler sex ia pahami bukan hanya sebagai fenomena biologis, melainkan sebuah konstruk ideal yang dimaterialkan oleh waktu dengan cara memaksa dan terusmenerus melalui norma-norma pengaturan. Sehingga dalam sex terdapat regulasi yang mendisiplinkan tubuh. Jika Foucault menempatkan seksualitas sebagai sesuatu yang terkonstruksi (Foucault, 1978), Butler menarik konsep ini lebih jauh dalam termaterialisasikannya seksualitas dalam tubuh. Tubuh tidak hanya dipahami sebagai plat yang di atasnya kemudian dibentuk seksualitas dan gender, namun gender dan seksualitas itu sendiri yang dimateriilkan menjadi tubuh. Materialisasi merupakan pembentukan menjadi material, menjadi daging, menjadi darah, yang tidur, makan dan istirahat. Bagi Butler tubuh (saraf, darah, kontur dan gerakannya) termaterialkan oleh performativitas oleh pertunjukan.

Butler menggambarkan bagaimana kebenaran tentang gender dan seksualitas diproduksi dan direproduksi melalui serangkaian tindakan, gestur, dan hasrat yang mengimplikasikan identitas gender paling esensial. Waria, objek yang dikaji Butler, harus melakukan serangkaian praktik dan prosedural tertentu untuk memperoleh bentuk yang diidealkan di mana gestur dan penampilan mereka dianggap feminin. Praktik ini bagi mereka, menurut Butler, tidak sekedar menirukan femininitas perempuan. Lebih jauh, mereka juga menunjukkan bahwa femininitas adalah sebuah praktik peniruan, baik itu ketika dilakukan waria maupun perempuan.

Dengan demikian, waria bukan sedang meniru yang asli, melainkan menginspirasikan bahwa yang asli itu tidak ada, yang ada hanyalah layers of performances hingga membentuk efek yang benar-benar dianggap alamiah. Penentu the effect of realness adalah kemampuan untuk menghasilkan naturalised effect (Butler, 1993). “... The notion of an original or primary gender identity is ... parodied within the cultural practices of drag, crossdressing, and the sexual stylisation of butch/femme identity ..." (Butler, 1993). Tidak ada identitas gender di balik ekspresi gender, karena gender adalah sebuah proses imitasi, pengulangan dan performativtas yang tidak pernah berhenti. Identitas gender, karenanya, bukanlah sebuah hal yang tetap. Melalui proses imitasi, heteroseksualitas dinaturalkan dengan proses yang terus menerus dan berulang-ulang.

Teori performativitas Butler disalahpahami sebagai enactment gender dan seks sebagai daily choice (Butler, 1993). Artinya, gender bisa diperlakukan seperti pakaian, besok mau memakai yang ini, besoknya itu, pemilihan yang berada dalam 
intensionalitas. Untuk menjelaskan hal ini, Butler menekankan pentingnya repetisi dalam performativitas, dengan menggunakan teori Derrida tentang iterabilitas, sebuah bentuk sitasionalitas, suatu proses di luar pilihan-pilihan sadar dan sengaja.

Apa implikasi iterabilitas dan sitasionalitas bagi naturalitas seks dan naturalitas tubuh dalam teori performativitas? Bagi Butler gender dan seks bukanlah sebuah kondisi, melainkan adalah pertunjukan terus-menerus yang bukan hanya membentuk keaslian jenis kelamin melainkan juga mematerialisasikan jenis kelamin. Seks bukanlah sebuah fakta simpel dan kondisi statis tubuh, melainkan proses ketika norma-norma pengatur mematerialkan seks dan mencapai materialisasi ini melalui pengulangan norma itu secara terus-menerus dan dipaksakan. Pengulang-ulangan ini menunjukkan bahwa materialisasi itu tidak pernah tercapai, tubuh juga tidak pernah berhasil benar sesuai dengan apa yang diharapkan.

Apa kaitan antara performativitas ini dengan materialitas? Performativitas tidak dipahami sebagai tindakan singular dan sengaja tetapi sebagai tindakan terusmenerus dan sitasional, melalui diskursus menghasilkan efek yang dinamainya. "Norma-norma pengatur tentang seks berfungsi secara performatif untuk membentuk materialitas tubuh, materialitas seks, dan mematerialkan perbedaan seksual dalam rangka untuk mengkonsolidasikan ideologi imperatif heteroseksual" (Butler, 1993). Gender dan seks kita adalah pertunjukan, dan hasil pertunjukan, yang dimaterialkan oleh pertunjukan.

Lakuan aksi para waria Sedap Malam yang penulis teliti, baik dalam keseharian maupun dalam pertunjukan-pertunjukan Sedap Malam merupakan proses imitasi yang dilakukan secara terus-menerus dan berulang-ulang. Dalam aktivitas sehari-hari diantara para waria barangkali Nining Kusim yang paling dominan. Nining Kusim bahkan memiliki ritual keperempuanan yang melebihi ritual perempuan 'normal' atau kebanyakan perempuan.

Paguyuban Sedap Malam mempunyai jadwal pertemuan rutin sebulan sekali yang berwujud arisan. Arisan ini dilakukan di rumah mereka secara bergantian atau kadang mereka mencari tempat di luar rumah. Dalam setiap arisan tersebut Nining Kusim pasti akan memakai rok baru, sandal atau sepatu baru, aksesoris baru, tas baru dan barang-barang keperempuanan lainnya. Nining Kusim dengan sengaja selalu datang terlambat pada setiap pertemuan, kalau bisa ia datang paling akhir. Hal ini ia lakukan untuk memamerkan barang-barang keperempuanannya, tentu saja ia datang paling akhir supaya semua teman-temannya bisa melihat kualitas keperempuanannya. Lakuan aksi yang dilakukan Nining Kusim ini tak ubahnya seperti saat melakukan pergelaran, ia menggunakan teknik muncul pada saat kedatangan di setiap arisan. Teknik muncul yang paling sering ia gunakan adalah berjalan melenggak-lenggok selayaknya model berjalan di catwalk.

Saat penulis mengikuti satu pertemuan arisan tersebut Nining Kusim juga datang paling akhir, ia mengendarai sepeda motor. Pertemuan dihelat di rumah Dwi Utami, karena saat itu kami semua berada diteras rumah maka kami semua melihat kedatangannya. Ia langsung membunyikan klakson, berhenti, melepas helm, turun dari motor, semua gerakan dilakukan dengan kemayu. Masih dengan kemayu sambil berlenggak-lenggok seperti model ia berkata,

"Haaiii semuanya! Awas! Perhatian perhatian! Mohon kasih jalan ya ... Syahrini mau lewat! Hari ini Syahrini pakai rok baru, sandal baru, jam tangan baru, cincin baru, kerudung baru, dan tas baru! Cantik gak? Cantik gak? Cantik gak? Cantik dong ya?! Ah kalian mah 
gak ada apa-apanya ... Maju mundur maju mundur maju mundur cantiiiik!".

Nining Kusim terlihat paling perempuan diantara para waria Sedap Malam yang lain, dalam keseharian barangkali dipengaruhi oleh betapa sulitnya ia menghadapi orang-orang terdekatnya yang kontra terhadap pilihan gendernya. Orang-orang terdekat Nining Kusim terutama bapaknya marah luar biasa ketika pertama kali mengetahui Nining Kusim seorang waria. Secara emosional bapak Nining Kusim bahkan sempat menghajar Nining Kusim dengan pukulan, makian, dan tendangan, sebelum ia diselamatkan oleh paman dan ibunya.

Bentuk-bentuk performansi imitatif yang dilakukan secara terus-menerus dan berulang-ulang oleh para waria Sedap Malam dalam keseharian yang cukup kuat juga tampak pada sosok Ambar Handoko dan Santi Marwan. Mereka berdua samasama memakai BH. Ritual keperemuanan yang dilakukan Santi Marwan tidak sebanyak Nining Kusim dan Ambar Handoko. Santi Marwan hanya akan memilih beberapa saja, yang paling sering dan selalu ia lakukan adalah merias wajah dan memakai BH. Selebihnya ia akan memilih salah satu saja diantara memakai gelang, kalung, atau anting.

Ambar Handoko dalam keseharian memiliki ritual menata rambut, merias wajah, mengecat kuku, memakai $\mathrm{BH}$, memakai anting, memakai kalung, dan memakai gelang dalam jumlah banyak. Rambut menjadi penanda penting bagi perempuan dalam normativitas masyarakat. Bahkan ada ungkapan yang menyebutkan bahwa rambut adalah mahkota wanita.

Penampilan fisik para waria baik dalam keseharian maupun dalam pertunjukan-pertunjukan Sedap Malam yang diidentifikasi oleh masyarakat sebagai identitas gender dijadikan sebagai sarana untuk memperformansi gender yang mereka inginkan. Mereka oleh masyarakat dianggap sebagai perempuan melalui ritual-ritual keperempuanan, terutama ketika dalam pertunjukan.

Para Kleting dan Kualitas Feminitas

Feminitas secara umum memiliki definisi sebagai hal yang memiliki sifat feminin yaitu ciri-ciri yang diidentikkan dengan sifat keperempuanan. Feminitas merujuk pada kualitas kewanitaan menurut konstruksi sosial walaupun perbedaan fisik yang membedakan perempuan dengan lakilaki menjadi satu alasan di sisi lain. Menurut KBBI Edisi Keempat (2008), feminitas merupakan sesuatu yang menyangkut perihal perempuan; kefemininan. Feminitas berasal dari kata bahasa Inggris yaitu femininity yang memiliki signifikasi sebagai kualitas menjadi perempuan atau dengan kata lain kualitas keperempuanan. Pada umumnya, sosok perempuan diidentikkan dengan sifat-sifat feminin seperti keibuan, keanggunan, kelembutan, kecantikan, dan lain-lain. Atribut feminin tersebut merupakan anggapan yang berkembang dalam masyarakat tentang figur perempuan ideal. Dengan kata lain, feminitas dibentuk oleh konstruksi sosial mengenai sifat keperempuanan.

Menurut Kristeva (1941), konsep 'femininitas' merupakan metafora bacaan dan bagian dari topografi tulisan, dan kedua hal tersebut ditampilkan sebagai alternatif dari metafora atau simbol paternal. Sama halnya dengan femininitas, bahasa juga merupakan sebuah konstruksi sosial. Pilihan kata yang sering dipakai untuk laki-laki dan perempuan berbeda. Misalnya, perempuan diasosiasikan dengan kata sifat manis, menarik, yang jarang disebutkan pada lakilaki. Peran tersebut merupakan konstruksi sosial dan budaya yang merepresentasi kondisi dan situasi masyarakat pengguna bahasa tersebut (Udasmoro, 2018). 
Femininitas dan maskulinitas adalah istilah yang terus-menerus berubah. Menurut Ballaster, Beetham, Frazer, dan Hebron dalam esai A Critical Analysis of Women's Magazines (dalam Prabasmoro, 2006) bahwa perempuan tidak dapat didefinisi semata-mata dalam ukuran yang negatif; femininitas harus diberikan suatu konteks tertentu.

Kontestasi keperempuanan para waria dalam pertunjukan ketoprak Sedap Malam lakon Ande Ande Lumut berpusat kepada tokoh para Kleting. Para Kleting ini berjumlah empat orang yaitu, Kleting Kuning, Kleting Biru, Kleting Abang, dan Kleting Bisu. Kualitas feminitas keempatnya membuat para penonton kadang lupa kalau mereka sebenarnya secara biologis adalah laki-laki.

Adegan pembuka pertunjukan ketoprak Sedap Malam lakon Ande Ande Lumut berupa tari Gambyong, dilakukan oleh Kleting Merah yang diperankan oleh Dwi Utami, Kleting Biru diperankan oleh Cindi Kartolo, dan Kleting Bisu diperankan oleh Endang Sukardi. Gerakan menari ketiganya tampak luwes dan lembut. Keluwesan dan kelembutan gerakan menari mereka tampak sulit dibedakan dengan perempuan sesungguhnya.

Pada adegan pembuka juga terdapat tembang, yang dinyanyikan oleh Dwi Utami. Sambil menari dengan anggunnya Dwi Utami menyanyi dengan suara persis suara perempuan. Kualitas feminitas Dwi Utami memang tidak diragukan lagi, dialah ikon Sedap Malam. Semua mata penonton tidak berkedip saat melihat Dwi Utami menari sambil nembang. Mereka sulit percaya bahwa Dwi Utami bukanlah perempuan secara biologis. Melihat reaksi para penonton yang begitu kagum kecantikan, keluwesan, dan keindahan suara Dwi Utami, membuat Cindi Kartolo dan Endang Sukardi tidak mau kalah untuk ikut kemayu menunjukkan kualitas feminitas mereka berdua.

Adegan selanjutnya adalah adegan bertemunya ketiga Kleting dengan Mbok Randha Pesirapan, ibu mereka. Dalam adegan ini Mbok Randha Pesirapan memberitahu kepada anak-anaknya bahwa ia mendengar ada pemuda tampan bernama Ande Ande Lumut mengadakan sandiwara, barang siapa perempuan datang ikut sandiwara yang menarik hatinya maka akan ia jadikan sebagai istri. Mendengar itu Kleting Biru dan Kleting Bisu semakin luar biasa kemayunya. Mereka berdua meminta kepada ibunya untuk merias wajah mereka secantik mungkin agar mereka dijadikan istri Ande Ande Lumut. Tiba-tiba terdengar celetukan seorang penonton. Seorang penonton laki-laki muda tiba-tiba berdiri lalu setengah berteriak berkata,

"Kene tak dandani kene, ben uwayu!"

("Sini saya rias, biar cantik!")

Cindi Kartolo dan Endang Sukardi tanpa berpikir panjang kemudian setengah berlari menuju pemuda tadi. Mereka berdua menyodorkan wajah mereka dengan lebih kemayu dari sebelumnya. Pemuda itu pun tidak berkutik, diam saja sambil menahan perasaan malu. Semua penonton menjadi kompak menertawakan tingkah Kleting Biru dan Kleting Bisu yang sangat menggemaskan.

Adegan berikutnya ialah adegan bertemunya Kleting Merah, Kleting Biru, dan Kleting Bisu dengan Yuyu Kangkang. Betapa kemayunya mereka bertiga ketika kaget melihat penampakan Yuyu Kangkang. Lagi-lagi ekspresi kaget yang sangat kemayu dari ketiga waria ini membuat penonton semakin gemas. Hal ini terlihat dari reaksi penonton yaitu; memukul sendiri kedua pahanya berulang-ulang, memukul teman sebelahnya, dan memukul kursi.

Yuyu Kangkang menawarkan untuk menyeberangkan Kleting Merah, Kleting Biru, dan Kleting Bisu dengan syarat mereka bertiga mau menciumnya. Pada saat 
para Kleting ini masih dalam keadaaan kebingungan tiba-tiba terdengar teriakan salah seorang penonton. Seorang pria paruh baya berteriak dengan semangat,

"Kang Yuyu Kan gkang, nyoh tak wenehi dhuwit satus ewu ning sing diambung aku. Sampeyan tak ganteni!",

(Kang Yuyu Kangkang, saya kasih uang seratus ribu tapi saya yang dicium ya. Kamu saya wakili!").

Seperti yang sudah-sudah, Dwi Utami, Cindi Kartolo, dan Endang Sukardi langsung berlari menuju sumber suara. Dwi Utami yang tiba duluan langsung menyambar uang seratus ribu yang ditawarkan lalu mencium pipi kanan pria paruh baya tersebut. Selanjutnya Cindi Kartolo mencium pipi kirinya. Terakhir Endang Sukardi dengan ekspresi paling kemayu mencium kening pria tersebut seolah-olah seperti mencium kekasihnya. Ending Sukardi mencium dengan memonyongkan bibirnya terlebih dahulu. Penonton semakin terbahak-bahak melihat adegan konyol dan lucu tersebut.

Kleting merah yang diberi tes Mbok Randha Dhadhapan untuk menari dan menyanyi semakin menunjukkan kualitas feminitasnya. Dia menari dengan begitu lembut, terlihat anggun, luwes, melebihi perempuan sesungguhnya. Suaranya pun demikian, betul-betul mirip dengan suara perempuan yang cantik. Sementara itu Kleting Biru yang merasa tidak bisa dites apapun memilih untuk pura-pura pingsan. Para penonton tertawa terbahak-bahak melihat ekspresi pingsan Kleting Biru. Giliran terakhir adalah tes untuk Kleting Bisu, karena adegan menjadi agak monoton tiba-tiba Endang Sukardi melakukan improvisasi. Ia yang seharusnya memerankan tokoh bisu tiba-tiba bisa berbicara dengan lancar dan jelas. Merasa mendapatkan momentum, Endang Sukardi berdialog dengan lebih kemayu. Lagi-lagi untuk kesekian kalinya tawa dan tepukan penonton membahana malam itu.
Puncak kualitas feminitas dari para Kleting ditutup dengan ditolaknya Kleting Merah, Kleting Biru, dan Kleting Bisu oleh Ande Ande Lumut. Orang yang ditolak cintanya tentu saja seharusnya mengeluarkan ekspresi sedih. Sebetulnya mereka juga terlihat sedih, namun ekspresi sedih mereka adalah ekspresi sedih yang sangat kemayu. Mereka bertiga berekspresi seolah-olah diri mereka adalah bintang sinetron yang sedang akting sedih ditindas oleh sang tokoh antagonis, hal ini nampak jelas saat Endang Sukardi tiba-tiba berkata:

"Piye bapak-bapak? Lak pun mirip Aura Kasih ta?"

("Bagaimana, bapak-bapak? Sudah mirip Aura kasih kan?”)

sontak para penonton tertawa terpingkal-pingkal. Improvisasi

Endang Sukardi tersebut kemudian membuat Dwi Utami dan Cindi Kartolo kompak bereaksi dengan berteriak:

"Aura Kasih apa! Kowe kuwi aura gaib!!!”, (“Aura Kasih apa! Kamu itu aura gaib!!!”).

Kleting Kuning: Pencarian Subjek Tanpa Henti

Subjektivitas mengacu kepada kondisi sebagai pribadi dan proses di mana diri menjadi seorang pribadi. Sebagai subjek, yaitu sebagai pribadi, diri terikat kepada proses-proses sosial yang menciptakan diri sebagai subjek untuk diri dan orang lain. Berbicara tentang subjektivitas sama halnya bertanya apakah yang dimaksud dengan pribadi itu?

Persoalan gender hanya semata persoalan performativitas, proses imitasi, dan pengulangan yang tidak pernah berhenti (Butler, 1990). Karenanya, tidak ada yang dapat disebut sebagai identitas asli, yang ada hanya bentuk-bentuk impersonasi atau imitasi yang diulang-ulang, secara terus menerus, dan tidak bisa berhenti. 
Lakon Ande Ande Lumut dalam pertunjukan ketoprak Sedap Malam bersumber dari cerita Panji. Cerita Panji merupakan cerita yang berkisar mengenai percintaan Raden Panji Asmarabangun (Inu Kertapati atau Panji Kudawanengpati), putera mahkota kerajaan Jenggala, dengan Dewi Sekartadji (Galuh Candra Kirana), puteri kerajaan Panjalu atau Kadiri. Namun jalinan kasih sepasang sejoli ini tidak berjalan mulus, banyak romantika berupa petualangan dan penyamaran hingga Cerita Panji kemudian melahirkan banyak versi dan varian berupa dongeng dan kisah-kisah lainnya. Beberapa cerita rakyat seperti Andeande Lumut, Keong Mas, dan Golek Kencana merupakan turunan dari Cerita Panji.

Cerita Panji bukan hanya bercerita mengenai kisah percintaan belaka. Filosofi Cerita Panji adalah mengenai "mencari dan menemukan", seperti kisah tentang rembulan dan matahari yang digambarkan bagaikan sepasang kekasih. Bulan adalah lambang kesetiaan dan ketulusan cinta. Janji bulan adalah untuk tetap setia pada matahari. Berbagai varian Cerita Panji selalu mengisahkan upaya pencarian yang dilakukan dengan sungguh-sungguh, penuh dengan halang rintang, termasuk harus melakukan penyamaran. Cerita Panji mengajarkan perihal kesetiaan dan usaha keras dalam sebuah pencarian.

Begitu pun dalam lakon Ande Ande Lumut, tokoh Kleting Kuning dalam lakon Ande Ande Lumut digambarkan sebagai tokoh perempuan yang secara langsung maupun tidak langsung atau sengaja maupun tidak sengaja memasukkan ideologi feminis yang dibawa dalam bahasa wacana. Dapat dilihat seperti uraian berikut:

a. Rela Berkorban.

Fitrah perempuan yang dipaksa bertahan atau nrimo dengan keadaan dan rela berkorban terlihat pada sosok tokoh Kleting Kuning. Kleting Kuning orang yang ringan tangan dan berhati tulus, bahkan terhadap saudara-sauadara tirinya. Kleting Kuning, demi kakak-kakak tirinya bersedia melakukan apa saja; memasak, mencuci, membersihkan rumah dan pekarangan, dan pekerjaan rumah lainnya. Terlihat dari beberapa kutipan berikut:

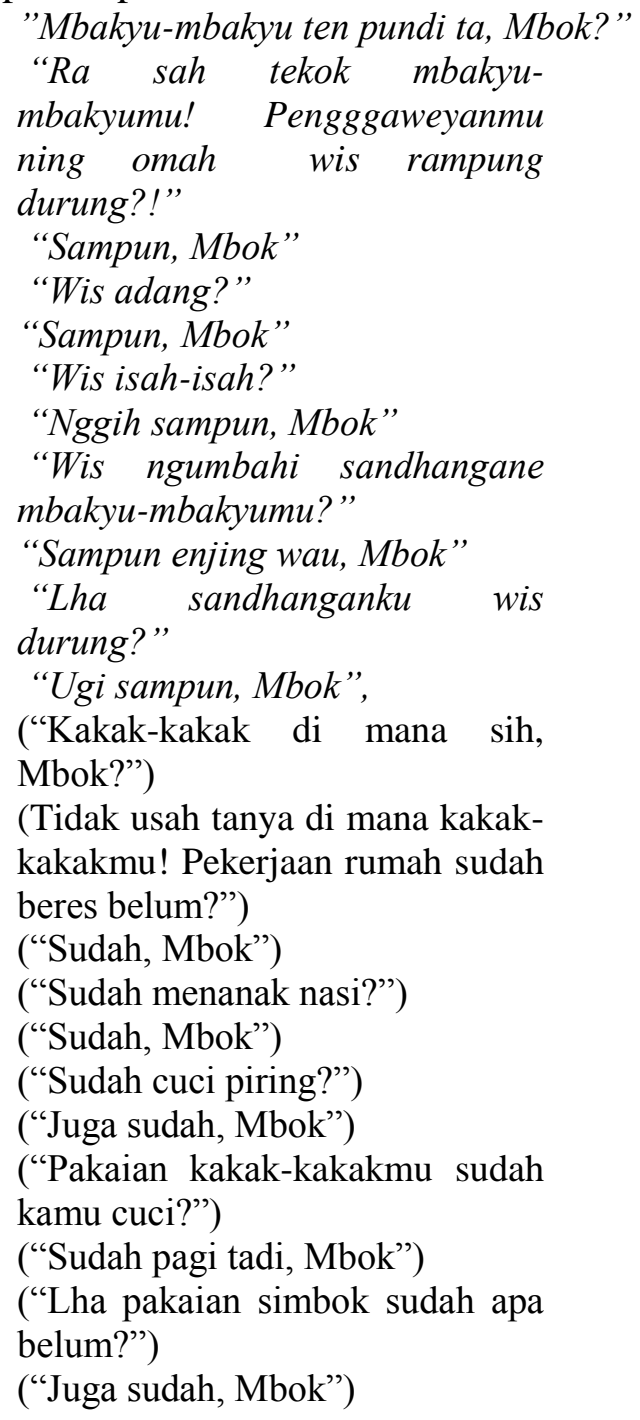

Dari kutipan dialog di atas terlihat jelas Kleting Kuning yang sejatinya adalah seorang putri raja rela melakukan pekerjaan kasar perempuan rendahan, sementara kakak-kakak tirinya hanya sibuk berdandan, bermain, dan bersenang-senang. Kleting Kuning masih dengan sabar tidak mempersoalkan perlakuan kasar kakakkakak tirinya, bahkan ketika dia dijadikan 
'kambing hitam' atas kesalahan kakakkakak tirinya di hadapan Mbok Randha Pesirapan.

\section{b. Aktualisasi Diri.}

Dari narasi cerita di atas terlihat ideologi aktualisasi diri tokoh Kleting Kuning, peran perempuan yang tidak melulu berkutat pada ranah domestik. Semua permasalahan pribadi yang melilit tokoh Kleting Kuning tidak membuatnya berkecil hati. Namun, menjadi pemicu untuk menggali potensi dan mencari jati diri agar hidup memiliki arti. Mengembara yang identik dengan identitas kelelakian, Kleting Kuning lakukan, bahkan Kleting Kuning memutuskan mencari suaminya padahal hal ini bersifat patriarki. Kleting Kuning lebih memperjuangkan haknya sebagai individu, terlepas dari permasalahan jenis kelaminnya yaitu perempuan.

\section{c. Pemberontakan}

Peran perempuan yang terkadang tersubordinat terlihat pula pada diri tokoh Galuh Candra Kirana atau Kleting Kuning. Kleting Kuning dengan berani mengambil keputusan mengembara untuk mencari suaminya sendirian. Dia sangat sadar akan apa yang menjadi permasalahan kaum perempuan dalam budaya patriaki sebagaimana yang dialaminya. Kleting Kuning mengerti pandangan masyarakat terhadap seorang perempuan. Perempuan dianggap lemah dan tidak berdaya tanpa bantuan dan perlindungan laki-laki. Bahkan perempuan sendiri, dalam hal ini contohnya ialah kakak-kakak tirinya yang terkadang memosisikan diri dalam situasi tersebut dengan nyamannya.

Kleting Kuning tidak hendak mengingkari kodratnya sebagai perempuan, Kleting Kuning hanya menginginkan kehidupan terbaik dalam pandangan umum budaya patriaki. Kleting Kuning ingin menampilkan dirinya yang mandiri, yang dalam banyak hal bisa memiliki kemampuan sama dengan kaum lelaki. Kleting Kuning memilih melawan Yuyu Kangkang, berbeda dengan kakak-kakak tirinya yang tunduk kepada Yuyu Kangkang ketika akan menyeberang sungai dengan syarat mau dicium.

Kleting Kuning lebih memperjuangkan haknya sebagai individu dan tidak ingin dirinya memiliki ketergantungan terhadap seorang laki-laki. Ideologi pemberontakan terhadap realitas yang terdapat pada diri Kleting Kuning ingin memperlihatkan posisi perempuan yang kuat. Luapan pemberontakan dilakukan dengan cara menarik diri dari dunia perempuan yang lemah dan asyik dengan dunianya yang mandiri. Lakon Ande Ande Lumut dalam alur cerita pengembaraan Kleting Kuning lebih memihak perempuan, karena Kleting Kuning dipertemukan dengan keluarga yang sama sekali tidak ada laki-lakinya.

\section{d. Keteguhan}

Kleting Kuning seorang yang memiliki prinsip hidup yang kuat. Karakter yang secara umum dipandang sebagai representasi kejiwaan seorang laki-laki. Namun, Kleting Kuning yang seorang perempuan pun bisa memegang teguh prinsip-prinsip hidupnya untuk selalu mandiri, tidak bergantung pada siapa pun. Keputusan untuk bertindak dan bersikap bukanlah perkara yang mudah diambil. Dibutuhkan keberanian, keteguhan, ketegasan, apalagi berkaitan dengan rencana masa depan. Perempuan dengan segala beban yang ditanggungnya adalah sosok yang sangat tangguh sehingga berani mengembara untuk mencari suaminya.

Kite Milet, seorang feminis radikallibertarian mengatakan bahwa androgini hanya menjadi ideal jika kualitas feminis dan maskulin, yang diintregasikan ke dalam manusia androgini adalah masing-masing 
berharga (Tong, 2010). Karakter Kleting Kuning sesuai dengan apa yang telah diungkapkan Kite Milet tentang kondisi ideal sebuah keadaan yang disebut androgini. Kleting Kuning tidak memunculkan arogansi yang identik dengan maskulinitas ataupun kepatuhan yang disebut sebagai ciri khas perempuan dalam pandangan budaya patriarki.

Saat tidak ada orang lain yang diharapkan membantu menyelesaikan permasalahan yang timbul, Kleting Kuning bisa dengan mudah memberdayakan dirinya. Kleting Kuning menjadi lebih mudah dalam menjalani kehidupan dalam lingkungannya. Keberadaan Kleting Kuning sangat menguntungkan bagi keluarga Mbok Randha Pesirapan. Kleting Merah, Kleting Biru, dan Kleting Bisu tidak perlu melakukan pekerjaan rumah, karena semua pekerjaan telah diselesaikan oleh Kleting Kuning dengan baik tanpa keluh kesah sedikit pun.

Dalam pertunjukan ketoprak Sedap Malam lakon Ande Ande Lumut, pencarian Kleting Kuning sebagai subjek tidak pernah berhenti. Dalam lakon Ande Ande Lumut secara umum, setelah membujuk Mbok Randha Pesirapan, ibu tirinya, untuk bisa ikut melamar Ande Ande Lumut kemudian juga telah berhasil menaklukkan Yuyu Kangkang sehingga bisa menyeberang sungai, Kleting Kuning seharusnya bertemu dengan suaminya. Namun, dalam pertunjukan Sedap Malam Ande Ande Lumut bukanlah Panji Asmara Bangun suami Galuh Candra Kirana, melainkan pemuda bisu tanpa identitas yang jelas. Pada akhirnya Kleting Kuning menolak menikah dengan pemuda tersebut dan memilih untuk akan terus mencari suaminya tanpa henti. Kleting Kuning adalah proses menjadi subjek yang utuh itu sendiri. Kleting Kuning adalah subjek yang terbelah, subjek yang terpinggirkan, sama halnya dengan para waria Sedap Malam. Kleting Kuning dan para waria Sedap Malam sebagai subjek yang terpinggirkan selalu akan melakukan proses mencari. Proses pencarian itu dilakukan oleh Kleting Kuning untuk menjadi subjek yang utuh atau sempurna. Subjek yang utuh atau sempurna bisa dikatakan adalah bahwa puncak keperempuanan itu tercapai pada saat perempuan bersuami.

\section{Simpulan}

Pertemuan para waria dengan Sri Riyanto menjadi gerbang pembuka kontestasi performativitas para waria Sedap Malam. Sri Riyanto menjadi alat bagi para waria untuk menunjukkan keperempuanan mereka. Ruang yang diciptakan Sri Riyanto yaitu panggung pertunjukan Sedap Malam berupa pertunjukan ketoprak, tari, cucuk lampah, dan guyon maton.

Melalui panggung, para waria menunjukkan identitas mereka, pilihan gender mereka, mengeluarkan hasrat mereka ingin diakui sebagai perempuan. Melalui panggung, hasrat para waria ingin diakui sebagai perempuan diterima oleh orangorang. Melalui panggung, lakuan-lakuan aksi dilakukan secara berlebihan oleh para waria. Ekspresi heboh, gestur heboh, berdandan heboh, pakaian heboh, segala tindakan mereka dilakukan secara heboh.

Produksi tanda keperempuanan oleh para waria dalam pertunjukan ketoprak Sedap Malam dalam lakon Ande Ande Lumut menunjukkan aksi hiperbolis, super heboh, dan berlebihan. Melebih-lebihkan itu bisa dipandang sebagai sebuah "pengukuhan", pengukuhan atas subjek, identitas para waria. 'Pengukuhan' ini juga sebagai sebuah 'perlawanan' terhadap anggapan negatif masyarakat atas gender yang dipilihnya.

Panggung pertunjukan Sedap Malam bersifat maya, sedangkan realita kehidupan sehari-hari yang dilalui bersifat nyata. Para waria secara psikologis selalu dihantui 
angapan masyarakat bahwa dalam realita sehari-hari mereka laki-laki. Para waria selalu merasa tidak yakin orang-orang mengakui keperempuanannya, pilihan gendernya. Oleh karena itu baik di dunia maya maupun nyata, para waria akan selalu melakukan produksi atau reproduksi tanda atas gender mereka secara hiperbolis, terusmenerus, berulang-ulang, dan tidak pernah berhenti.

Artinya, para waria Sedap Malam berada dalam situasi di antara realitas dan hasrat. Dalam realitas orang-orang menganggap para waria Sedap Malam 'sakit', sementara di panggung orang-orang menerima, orang-orang takjub dengan keperempuanan para waria. Hal ini membuat para waria berusaha keras memenuhi hasrat, di panggung mereka melakukan lakuanlakuan aksi yang heboh, berlebihan, bahkan aksi yang berlebihan itu dilakukan secara ekstrim.

Ekstrimitas keperempuanan dalam pertunjukan-pertunjukan Sedap Malam dilakukan oleh semua para waria. Mereka berkontestasi, berlomba menunjukkan keperempuanan mereka secara terus menerus, berubah dari satu situasi ke situasi yang lain. Untuk menjadi subjek yang utuh para waria Sedap Malam akan selalu mencari, mencari, dan mencari. Dalam proses mencari, para waria Sedap Malam akan selalu menunjukkan ekstrimitas keperempuanannya.

\section{Daftar Pustaka}

Alimi, M. Y. (2004). Dekonstruksi Seksualitas Poskolonial: dari Wacana Bangsa hingga Wacana Agama. Yogyakarta: LkiS,.

Barker, C. (2008). Cultural Studies: Teori dan Praktik (terjemahan Nur Hadi). Yogyakarta.

Butler, J. (1993a). Gender Trouble: Feminism and the Subversion of Identity. London dan New York: Routledge.

Butler, J. (1993b). Bodies That Matter: On the Discursive Limits of "Sex". London dan New York: Routledge.

Collard, A. \& Contrucci. (1988). Rape of the Wild. London: Women's Press.

Foucault, M. (1978). The History of Sexuality: An Introduction, Vol.1, (Trans) Histoire de la Sexualite. New York: Random House Inc.

Giddens, A. (1991). Modernity and SelfIdentity. Cambridge: Polity Press.

Prabasmoro, A.P. (2006). Kajian Budaya Feminis: Tubuh, Sastra, dan Budaya Pop. Yogyakarta: Jalasutra.

Ratna, N. K. (2004). Teori, Metode, dan Teknik Penelitian Sastra: Dari Strukturalisme hingga Postrukturalisme Perspektif Wacana naratif. Yogyakarta: Pustaka Pelajar.

Tong, R.P. (2010). Feminist Thought. Yogyakarta: Jalasutra.

Udasmoro, W. (2018). Dari Doing ke Undoing Gender: Teori dan Praktik Dalam Kajian Feminisme. Yogyakarta: UGM Press. 